July, Aug., Sept., 1951

\title{
Mountain Memories
}

\author{
By Elizabeth B. Flock
}

$\mathbf{D}^{-12}$ URING our June holiday in Banff and Yoho National Parks it was a pleasure to see again beauty spots not visited for years, whHe along the Jasper Highway and in Jasper $\mathrm{Na}-$ tional Park all was new country. The awesome grandeur of the scenery as we saw it in sunshine, rain and snow was an everchanging panorama of which we never tired.

Glaciers of all sizes became a common sight. The slowness of formation, the unseen motion forward or back, make them objects of wonder. It is one thing to read of the receding glaciers, but quite another to see how they have dwindled. The Athabasca glacier is now a mile from where it extended when discovered fifty years ago.

In Yoho valley we saw the havoc wrought by a snow slide of last winter. Masses of snow had tumbled from one side of the valley across the.floor and piled part way up the opposite wall. Every tree in the path had been taken along with the snow in a jumbled mass of debris. Large trees left standing along the edge were splintered and twisted as if torn by giant hands. The road had been cleared leaving a solid wall of snow, that would be a long time in melting, on each side.

At every opportunity excursions were made on font to see what plants might be found, both old friends and new ones. In the open country were shrubby cinquefoil. gallardia, red Indian paintbrush, blue flax, purple wild geranium, several members of the pea family. The wet places had quantities of shooting star with here and there a few butterworts and small clumps of round-leaved orchis. White globe flower, Labrador tea, saxifrage, purple clematis, green orchids, blue lungwort were abundant.

Sweet androsace was a new species with its cluster of small white flowers on top of a short, erect stem. The nodding yellow flowers of Drummund's dryas covering gravel bars and rocky ledges were another "first" since previously only the feathery seeds had been left later in the season.
The real find was on a solitary walk from our cabin on Tunnel mountain in Banff when beside the trail my eye fell on a clump of mauve-pink Calypso orchids. They looked so exactly like the many pictures in various botanies that I knew them at once. In his "Hill Top Tales". Dan McCowan mentions that the King and Queen saw these rare orchids along the Bow river in 1939.

Yet another new. species was a true alpine plant growing near the Athabasca glacier, part of the Columbia Icefields. The purple flowers of moss campion dotted the solid clump of moss-like leaves that hugged the rocks. This low plant grows from a surprisingly large taproot.

At Bow Summit where spring had not left, tiny willows bore huge catkins and spring beauty covered the wet ground in places along with violets. One of the fascinations of mountain country is the change of seasons from one elevation to another.

Birds are not overabundant in timbered country, nor are they easy to see. There were pine siskins, mountain chickadees and bluebirds, Canada jays, Clark's nutcrackers, Tennessee warblers, Montana juncos, red-necked grebes, common loons, red-hafted flickers seen at various times. Moraine lake yielded a pair of harlequin ducks which are wellnamed. I have searched many a mountain lake over the years looking for them in vain.

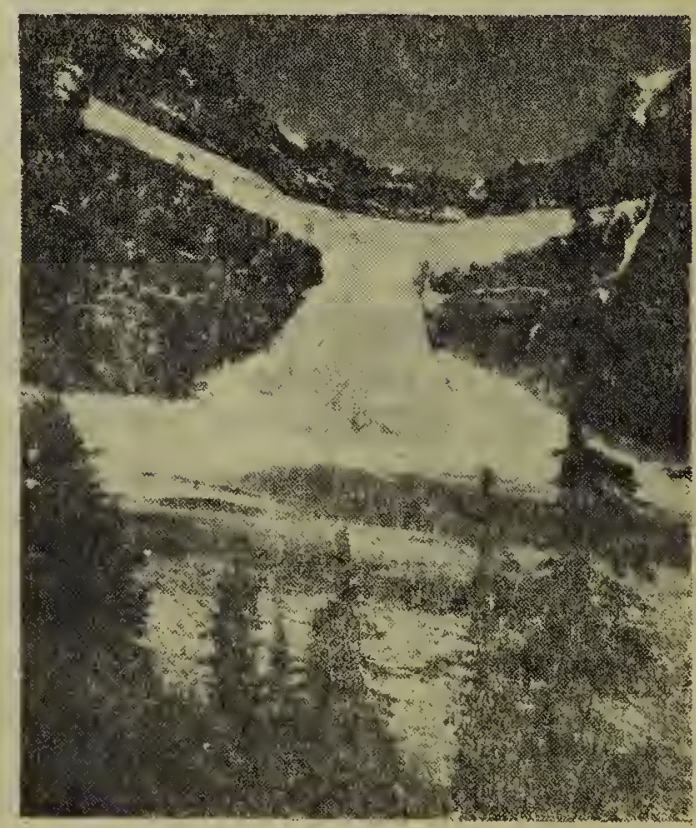


In Johnson canyon, by sheer luck, I spotted a rufous hummingbird on her nest. It was on the sloping branch of a small bush overhanging the water and visible from only one spot. Frequently, she dashed from the nest to dip her bill into wild currant blossoms nearby. The day before I had caught the flash of red on the throat of a male rufous hummingbird as he rested on a wolf willow branch beside the Bow river.

Animals in the National Parks probably arouse more interest than anything else. Being fully protected. they go about their daily lives in full view of gazing tourists.

On many occasions moose fed in the marshes alternately plunging their heads into the water and coming up dripping, with a mouthful of plants which they proceeded to chew while cameras clicked and people stared. One especially fine specimen with magnificent antlers still in the "velvet" was close to the highway as it follows the Athabasca river.

Mountain sheep were seen frequently. Four rams made a tableau as they were eating something just outside the dining room windows at the Columbia Icefield Chalet. Suddenly two seemed to want the same morsel. With heads lowered, they backed away and then met head on in a terrific impact which seemed to clear the atmosphere. Later, in single file, they marched out of sight up the mountain.

Elk roamed the islands in the Bow river at sunset where we could spot them from above. The largest herd we saw was in Jasper not far from the townsite. They were a majestic picture trotting or walking over an open ridge from one feeding ground to another. Cows with calves dotted the steep hillside farther up.

Deer were seen often, some very tame. One buck licked salt from an outstretched palm as avidly as a small boy goes for sweets.

Along the Mt. Edith Cavell road a pair of golden-mantled ground squirrels had taken up residence at a "Viewpoint". No sooner did a car stop than they appeared hoping for a handout. At the end of the same road, the trail opposite Angel Glacier passed near the home of a hoary marmot that was busy eating as we walked by.
Of course, bears are the chief attraction since they line the highways to hold up motorists who choose to disregard the warning against feeding them. Many bears brought their cubs along. In June they were still very small and too cute for words. Some remained well off the road where they put in the time playing together or racing for a tree to climb if any unusual noise occured. One lone cub amused himself tearing up a bread wrap while his mother parked on the highway. If a car stopped beyond her she galloped up to meet it. The mother with three cubs had her hands full. She was being fed popcorn, but the cubs swarmed about the man imploring him with their looks while two clutched his legs. The mother sat back on her haunches or stood up as he raised or lowered his outstretched hand. Finally, one cub gave up and tried in vain to scramble into the back of the parked car. Every new noise sent him scurrying under the car only to reappear and make for the back seat again.

One evening along a trail we came upon two bear cubs playing. We were not sure whether the mother was near or not so made a hasty retreat up the steep incline without pausing for breath since we had no wish to mix with the mother. Later, under the trees not far from the road, we saw two cubs nursing and fancied they were the same, perhaps heading for the auto camp across the way. The mother kept sniffing the air and moving her head constantly while the cubs enjoyed supper. That was our choicest bear memory.

There is nothing like travel to enjoy "a fresh footpath, a fresh flower, a fresh delight."

\section{Spring and Summer Migrations}

(Continued from page 6)

the report of the Canada Goose nesting in a hawk's nest. It was only about three or four miles from our place but I didn't go to see it. I heard from reliable witnesses that quite a few people had seen it. The hawk's nest was twelve or fifteen feet from the ground on the "Flats" north of here. I believe the goose brought off her brood successfully. 